\title{
The Effect of Student Financial Constraints on University Non-Completion Rates
}

\author{
Evelyn Chiyevo Garwe ${ }^{1, *} \&$ Elizabeth Maganga ${ }^{1}$ \\ ${ }^{1}$ Zimbabwe Council for Higher Education, P. Bag H100 Hatfield Harare, Zimbabwe \\ *Corresponding author: Zimbabwe Council for Higher Education, P. Bag H100 Hatfield \\ Harare, Zimbabwe. Tel: 263-772-222-298 E-mail: garweec@gmail.com
}

Received: July 18, 2015

Accepted: June 27, 2015 Published: June 29, 2015

doi:10.5296/ije.v7i2.7927

URL: http://dx.doi.org/10.5296/ije.v7i2.7927

\begin{abstract}
The year 2009 saw the government of Zimbabwe redesigning cost-sharing in higher education to lean more towards higher contributions by students and private players. This study was aimed at investigating the effects that this strategy has on university completion rates by students from low socio-economic backgrounds. The study used a quantitative design methodology in a longitudinal study framework incorporating data from three cohorts embarking on four-year study programmes from 2009 to 2014. Administrative data from the Zimbabwe Council for Higher Education database involving six state universities was used. The findings reveal that the graduation rates decreased from $86 \%$ in the 2009 cohort to $76 \%$ in the 2010 cohort and $75 \%$ in the 2011 cohort. This finding coincides with the period from 2013 onwards when cadetship funds dried off. Thus the study clearly revealed a problem of increasing attrition rates creeping into the revered and quality-assured Zimbabwean higher education system. The study recommends the need for conceited efforts by the private sector, government and universities in funding higher education through loans and other forms of sponsorship.
\end{abstract}

Keywords: Dropout, university, quality, financial constraints, cost sharing 


\section{Introduction}

The decision to enrol for university studies has been described by Bakewell (2008) as one of most celebrated shifts in life towards absolute freedom, greater financial responsibility and more effective time management. It is therefore imperative to note that dropping out of university before completion of studies has personal, institutional and social repercussions. At the personal level, there are economic costs such as wastage of the sunken financial resources, the greater risk of unemployment coupled with lower lifetime productivity and earnings (Arulampalam, Naylor \& Smith 2005; Blundell, Sianesi \& Dearden, 2003; Ulriksen, 2010; Yorke, 1998). Dropouts also undergo emotional and psychological stress arising from feelings of inadequacy and low personal worth (Edwards \& Cangemi, 1990). For universities, dropouts are associated with financial loss and reduced academic reputation (Larsen, 2013; Vignoles \& Powdthavee, 2009). The university dropout or non-completion rate is a quality indicator in the evaluation (Cabrera, Tomás, Álvarez, \& Gonzalez, 2006; Draper \& Gittoes 2004) and ranking (Yorke, 1998) of universities. At the societal level, university dropouts represent higher education inefficiency because the supply of university graduates affects both the returns to education as well as economic growth (Aubyn; Pina, Garcia \& Pais, 2009; Fisher \& Hood, 1987; Bound \& Turner, 2011). In addition, high non-completion rates can undermine access to higher education, put off potential students and cause institutional instability (Lockhart, 2004).

Although the reasons for dropping out of university are many and varied, studies show that the socio-economic status of students is the most fundamental cause of non-completion rates world-over (CHE, 2013; Chen \& DesJardins, 2010; Letseka \& Maile, 2008; Lofstrom, 2007; Munro \& Fisher, 2004; Quinn, 2004; Titus, 2006; Vignoles \& Powdthavee, 2009; Walpole, 2003). Many of these studies indicate that students from less privileged family backgrounds have greater chances of dropping out of university as compared to those from well-to-do families (Blanden \& Gregg, 2004; Carneiro \& Heckman, 2003; Christie, Corrigan, 2003; Cunha \& Heckman, 2007; Davies \& Elias 2003; Dearing, 1997; Feinstein, 2003; Gayle, Berridge \& Davies, 2002; Haveman \& Wolfe, 1993; Meghir \& Palme, 2005; McGivney, 1996; Thomas \& Quinn, 2006; Vignoles \& Powdthavee, 2009). Some studies have alleged that the most powerful socio-economic determinant forcing students to withdraw from university is financial exigency (Bennett, 2003; Bozick, 2007; Davies, 2000; Leppel, 2002; Sanders, 2002). Similarly, a study carried out in East Africa revealed that financial constraints were the greatest challenge to completion of university education (Griffin, 2007). In South Africa, Letseka \& Maile (2008) reported that financial difficulties accounted for $70 \%$ of university drop-outs. It is therefore not surprising that several studies demonstrate that financial assistance is positively correlated to university completion (Alon, 2005; Adnett, 2006; Bean, 1983; Braunstein, McGrath \& Pescatrice, 2000; Cabrera, Nora \& Castañeda, 1992; Dowd \& Coury, 2006; Henry, Rubenstein \& Bugler, 2004; Hu \& St. John, 2001; Jensen, 1981, Kalsner, 1991; Perna, 1998; St. John, Hu \& Weber, 2001; Singell, 2004; Singell \& Stater, 2006). In fact Gross, Berry \& Reynolds (2015) declare that financial aid and completion rates are critical elements in the strategic management of academic success in higher education. 


\subsection{Cost-sharing strategies}

In line with the pervasive global trends in higher education financing, most countries in Africa have adopted the cost sharing strategy (Johnstone, 2006). For example, by 2009, more than 26 countries had adopted it (World Bank, 2010) including those countries that had earlier on implemented policies on free higher education (Mamdani, 2007; Musisi \& Muwanga, 2003; Wangenge-Ouma, 2008). Cost-sharing refers to the shared responsibilities of university costs of study between governments, institutions and students (Johnstone, 2004). The different forms of cost sharing adopted by each country are aptly described by Johnstone (2003). Although cost sharing has its merits, it has predisposed students from poor socio-economic backgrounds to the scourge of non-completion due to financial constraints. For example, McGregor (2007) found that in South Africa, students from low income families (average monthly family income of USD240) often drop out of university. Mdepa \& Tshiwula (2012) explain that although South Africa has an effective National Student Financial Aid Scheme, the bursaries and loans given only caters for part of the costs of study. Although there is no consensus on the appropriateness of the cost-sharing strategy, it has become entrenched in the global higher education system (Li, 2007; Woodhall, 2002).

Unlike other African countries that have historically implemented policies on free higher education, Zimbabwe adopted cost-sharing at the inception of the first university in 1957 (Chihombori, 2013). However, Zimbabwe has since shifted from one cost-sharing model to another as shown in Table 1.

Table 1. Cost-sharing models in Zimbabwean universities (1957-2014)

\begin{tabular}{|c|c|c|c|c|}
\hline Year & $\begin{array}{c}\text { Student } \\
\text { Enrolment }\end{array}$ & Grants $(\%)$ & Loans $(\%)$ & $\begin{array}{c}\text { No. of } \\
\text { Universities }\end{array}$ \\
\hline 1957 & 57 & 50 & 50 & 1 \\
\hline 1968 & Not given & 25 & 75 & 1 \\
\hline 1980 & 2240 & 50 & 50 & 1 \\
\hline 1991 & 9017 & 25 & 75 & 2 \\
\hline 1992 & & \multicolumn{2}{|c|}{ Introduction of private universities } & 3 \\
\hline 1998 & & 20 & 80 & 6 \\
\hline 2002 & & 0 & 100 & 11 \\
\hline 2006 & & \multicolumn{2}{|c|}{ Introduction of the Cadetship } & 14 \\
\hline 2007 & 55548 & \multirow{5}{*}{\multicolumn{2}{|c|}{ Scheme }} & 14 \\
\hline 2009 & 49645 & & & 14 \\
\hline 2010 & 54888 & & & 15 \\
\hline 2011 & 62427 & & & 15 \\
\hline 2012 & 64449 & & & 15 \\
\hline 2013 & 77074 & \multirow{2}{*}{\multicolumn{2}{|c|}{$\begin{array}{c}\text { Cadetship scheme operating below } \\
\text { optimum levels }\end{array}$}} & 15 \\
\hline 2014 & 85556 & & & 15 \\
\hline
\end{tabular}

Source: Adapted from Chihombori (2013) and Garwe (2014; 2015) 
Table 1 shows that the first cost-sharing model used from 1957 up to 1991 entailed the government covering the cost of the university tuition and upkeep for students through a system of grants and loans. The loans were then recovered as instalments upon completion and securing of employment by graduates. Upon achieving independence in 1980, the new government embraced the loan and grant cost-sharing model but shifted the proportion of grants and loans to 50:50 and later to 25:75 and 20:80 in 1991 and 1998 respectively. In addition, the government implemented strategies to improve access to higher education in order to expedite the country's socio-economic transformation (Mandaza, 1986; Nherera, 2000; Zvobgo 2003).

In 1992, the government also introduced another form of cost-sharing by opening up the higher education space to private players. These efforts resulted in an increase in the number of both public and private universities and the total student enrolment (Garwe, 2014). This increase coupled with inadequate loan recovery capacity posed severe challenges to the government's ability to adequately fund higher education. Consequently, in 2006 the government introduced a cost-sharing model which required students to pay tuition fee upfront before they could be allowed to register and attend classes. However, many students from low income backgrounds were unable to pay for university education (Chihombori, 2013). Noting these discrepancies, the government introduced the Cadetship Scheme to assist students facing financial hardships with tuition fees. However, cadetship funds only covered tuition fees thus leaving beneficiaries to pay for ancillary costs, levies and upkeep during the study period. The illegibility of students to qualify for cadetship posed a challenge as there were technical difficulties in authenticating the ability of the student to pay leading to potential abuse of cadetship funds. Similar challenges to means testing were reported in the Zambian context by Masaiti \& Shen (2013).

As from 2009 the number of students self-financing their studies increased tremendously and the level of government subsidies continued to decrease. From 2013 onwards, the cadetship scheme has been operating below the optimum level required to assist needy students. Private universities do not receive any subsidies from the government and their students pay full fees. There have been growing concerns that students who fail to pay fees are being forced to withdraw from university studies (Hwami, 2010; Makoni, 2007; Zimbabwe National Students Union, 2009). However, no study has been carried out to quantify the extent of this problem. From a background of very low dropout rates in Zimbabwean universities prior to 2006, it can be deduced that if indeed the graduation rates have decreased, the blame can be given to financial hardships. This study was therefore carried out with the aim of studying the effect of student financial constraints on university non-completion rates.

\section{Methodology}

\subsection{Research design}

The study used a quantitative design methodology to study the year-to-year progression and subsequent graduation rates. Cognisant of the suggestion by Wilson, Lizzio \& Ramsden 
(1997) for studies of this nature, a longitudinal study spanning from 2009 to 2014 was performed. The researcher used data on university student enrolment and graduation statistics from the database of that is kept by the Zimbabwe Council for Higher Education (ZIMCHE). Nordbotten (2012) avers that such data, collected for primary purposes other than research, is referred to as administrative data. Vignoles (2007) posit that administrative data can facilitate research that is of greater scope, more robust and can be generalisable. This is because administrative databases tend to be very comprehensive and thus enable longitudinal research that would otherwise be financially or logistically impossible to carry out using other methods (Whitworth, 2013). In addition to cutting costs, administrative data helps to avert the problem of low response rates arising from the use of laborious methods such as telephone calls, letters and one-on-one interviews. Einav \& Levin, (2013) believe that the use of administrative data has virtually transformed quantitative research predominantly in the area of education and health.

\subsection{Target population}

The target population for the study included all students who enrolled in four-year programmes at public universities in Zimbabwe. Data on enrolment and graduation statistics were collected for the six public universities that offer four year programmes. The other three public universities that offer predominantly three year programmes were excluded from the study. The six private universities were also excluded on the grounds that private universities and their students fund their programmes and thus it can be assumed that by choosing to enrol at a private university, the student would have done the cost/benefit analysis. Longitudinal data on enrolments was collected from 2009, 2010 and 2011 cohorts in their first and then every year in the second, third and graduation years (2012, 2013 and 2014). This allowed the researchers to fully examine the stages at which attrition took place. A cohort in this study refers to students who share the same year of admission to university in common.

\subsection{Procedure and data analysis}

The researchers obtained permission to collect the data on enrolment and graduation statistics from the database that is kept by the Zimbabwe Council for Higher Education. The data was aggregated by university and by degree programme. Only data from programmes that run for four years was included in this study. Analysis on the year-on year persistence rates and the subsequent graduation rates was done using the excel spreadsheet. In order to compare the persistence and completion rates for the three cohorts, the year-on year persistence rates were used before trend analysis was performed. Otherwise comparing the raw data was not going to be useful considering that there were large variations in student numbers per cohort.

\subsection{Methodological limitations}

The researchers were fully aware of the limitation in the methodology regarding the fact that it was not possible to identify students who could have left to undertake studies in other universities or who switched between programmes. The enrolment data for the second and subsequent years would also invariably be contaminated with repeat students from earlier cohorts. In addition, data on the socio-economic backgrounds of students could not be 


\section{Macrothink}

collected. However, the key assumption was that the significant factor that could affect completion of studies was financial constraints.

\section{Results}

\subsection{Student enrolments}

The student enrolments in Zimbabwean universities have shown an increasing trend since the establishment of the first university in 1957 as shown in Figure 1.

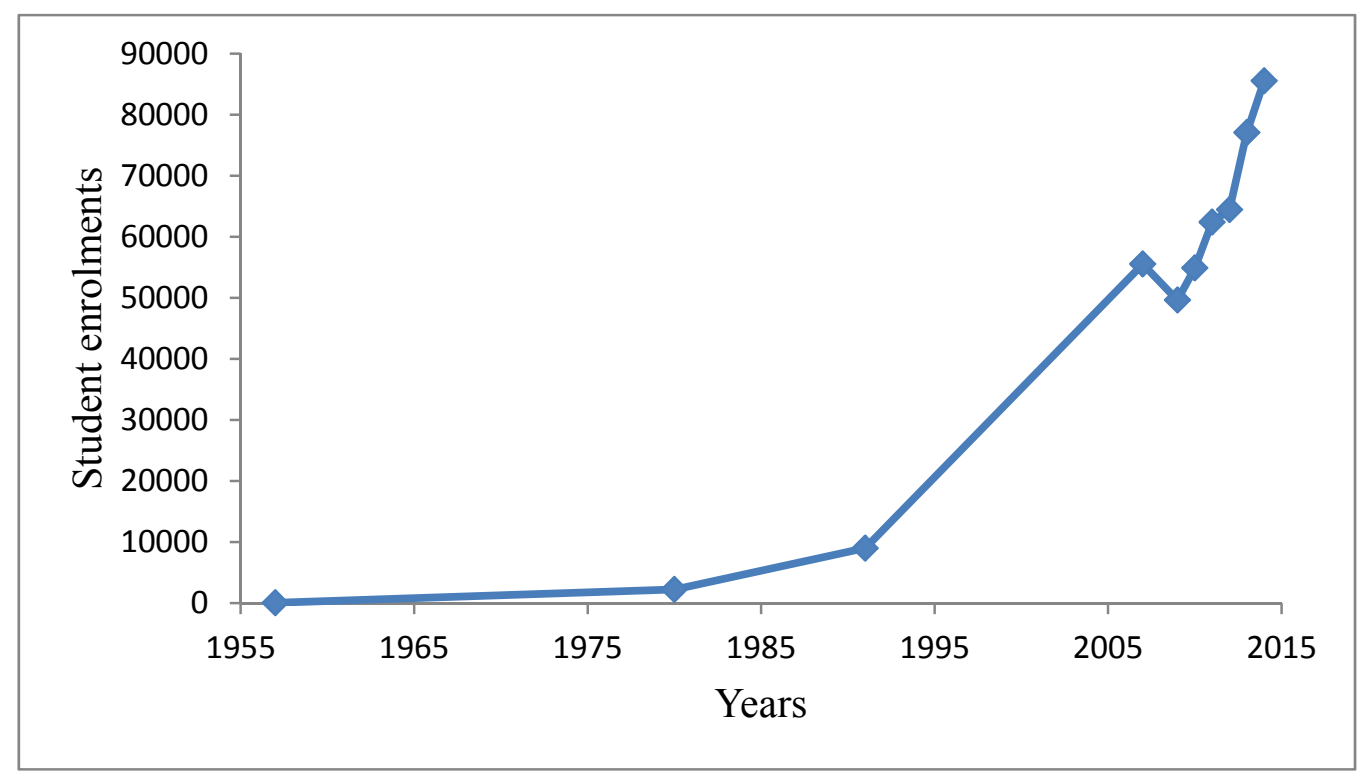

Figure 1. Trends in university student enrolment statistics (1957-2014)

The upward trend in student numbers shown in Figure 1 has not been matched with financial resources to provide loans, grants and cadetship support for students.

3.2 Year-on-year progression and graduation statistics for the 2009, 2010 and 2011 Cohorts

Table 2 shows the year-on-year progression and graduation statistics for the 2009, 2010 and 2011 Cohorts. 


\section{Macrothink}

Table 2. Year-on-year progression and graduation statistics (2009, 2010 and 2011 Cohorts)

\begin{tabular}{|c|c|c|c|c|c|c|}
\hline Institution & 2009 & 2010 & 2011 & 2012 & 2013 & 2014 \\
\hline & 794 & 729 & 700 & 658 & & \\
\hline & & 1006 & 920 & 889 & 800 & \\
\hline \multirow[t]{3}{*}{1} & & & 1600 & 1385 & 1100 & 1065 \\
\hline & 641 & 601 & 555 & 500 & & \\
\hline & & 1535 & 1402 & 1341 & 1169 & \\
\hline \multirow[t]{3}{*}{2} & & & 1950 & 1705 & 1500 & 1379 \\
\hline & 913 & 800 & 760 & 800 & & \\
\hline & & 369 & 360 & 349 & 320 & \\
\hline \multirow[t]{3}{*}{3} & & & 1300 & 1237 & 1007 & 880 \\
\hline & 332 & 311 & 300 & 271 & & \\
\hline & & 1535 & 1402 & 1341 & 1199 & \\
\hline \multirow[t]{3}{*}{4} & & & 420 & 380 & 345 & 289 \\
\hline & 1711 & 1600 & 1519 & 1497 & & \\
\hline & & 2503 & 1980 & 1800 & 1711 & \\
\hline \multirow[t]{3}{*}{5} & & & 4960 & 4524 & 4309 & 3931 \\
\hline & 1332 & 1299 & 1203 & 1187 & & \\
\hline & & 1520 & 1410 & 1325 & 1250 & \\
\hline 6 & & & 1800 & 1676 & 1585 & 1419 \\
\hline
\end{tabular}

The statistics from Table 2 show a gradual decline in the number of students from enrolment through to graduation. The completion rates for the three cohorts are shown in Table 3.

Table 3. Completion rates for the (2009, 2010 and 2011 Cohorts)

\begin{tabular}{cccc}
\hline Institution & 2009 Cohort & 2010 Cohort & 2011 Cohort \\
\hline 1 & 83 & 80 & 67 \\
2 & 78 & 76 & 71 \\
3 & 88 & 82 & 68 \\
4 & 82 & 78 & 69 \\
5 & 88 & 68 & 79 \\
6 & 89 & 82 & 79 \\
Average & 86 & 76 & 75 \\
\hline
\end{tabular}

Table 3 shows that different universities had different progression rates for the different cohorts. For example, university number 5 had the lowest graduation rate (68\%) for the 2010 cohort whilst university number 6 had the highest graduation rate $(82 \%)$. It can also be seen from Table 3 that graduation rates gradually decreased from $86 \%$ for the 2009 cohort to $75 \%$ for the 2011 cohort.

Figure 3 illustrates the trend in the year-on-year progression for the three cohorts from enrolment to graduation. 


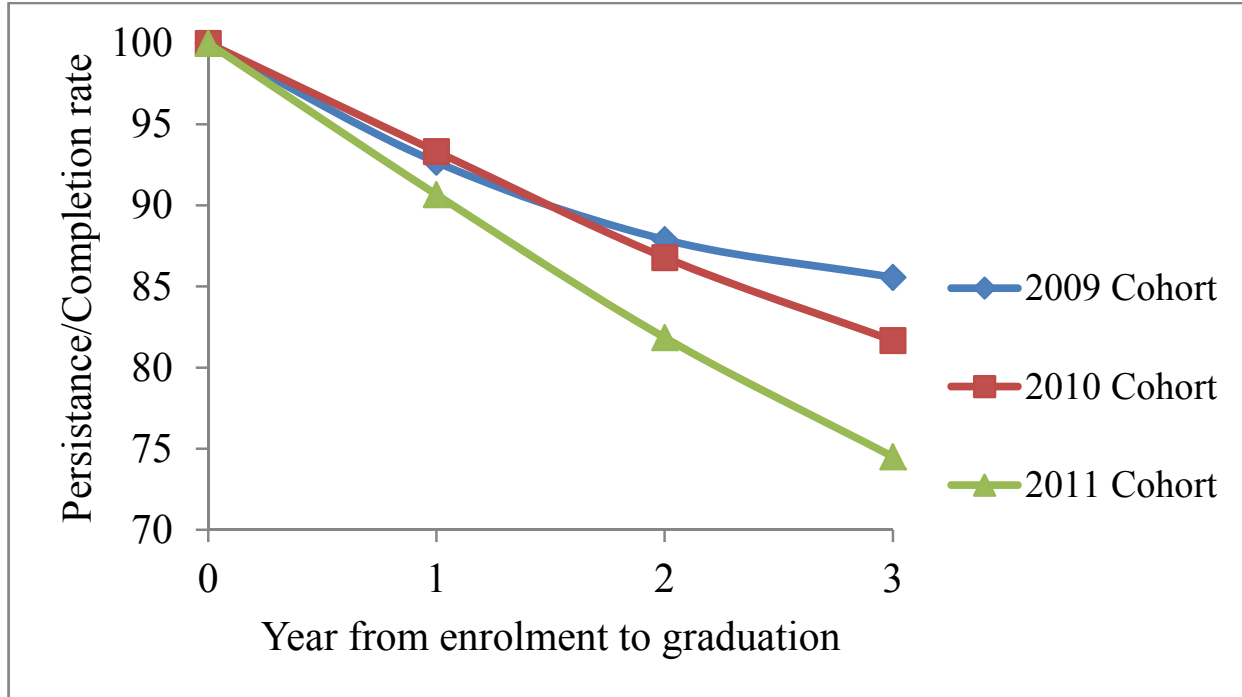

Figure 3. Year-on-year progression trends for the three cohorts from enrolment to graduation

Figure 3 shows that the 2011 cohort has the lowest progression and graduation rates. It also shows that the highest drop in progression rates occurs in year three.

\section{Discussion}

The findings reveal that the graduation rates decreased from $86 \%$ in the 2009 cohort to $76 \%$ in the 2010 cohort and $75 \%$ in the 2011 cohort. This finding coincides with the period from 2013 onwards when cadetship funds dried off. Although the year-on-year progression rates and graduation rates can be affected by many factors, it is the thesis of this study that in a country like Zimbabwe where graduation rates have always been upwards of $90 \%$, the only variable that can lead to marked decrease relates to financial constraints. Several studies corroborate with this finding that financial assistance is positively correlated to university completion (Bettinger, 2004; Bresciani \& Carson, 2002; DesJardins, Ahlburg \& McCall, 2002; Herzog, 2005; Somers, 1995). It can therefore be argued that the removal of any form of financial assistance can lead to poor academic outcomes in the university sector. Although the private sector has contributed a lot in funding higher education notably through student sponsorship, the impact seems to be minimal. Special mention goes to the contribution of Econet - Zimbabwe, Delta and British American Tobacco. These companies have provided funds to thousands of needy and/or brainy students to see them through university. Recently, a renowned educationist, Mrs Rosemary Sibanda, worked tirelessly to introduce Eduloan, an organisation responsible for providing loans for university education, a feat that even established banks seemed to shy away from. The effective participation of the private sector in funding university education has been reported in other countries. For example, Kyodo (2014) reported that in 2013 alone, the contribution of private spending in Japan accounted for $66.7 \%$ of the total funding on education.

The findings also showed that the year in which the most attrition of students took place is the third year of study. This is the year when students go for work-related learning as a way 
of including experiential learning in their curriculum (Rupande, 2013). Presumably due to the financial hardships, some students may prefer to continue working, thereby suspending or abandoning their studies. However, this proposition needs to be supported by a comprehensive qualitative study where the dropout students can proffer their opinions.

Much as this study focused on finances as the major cause of university student attrition in the Zimbabwean context, the researchers note that it is critical to undertake studies on other causes as well. The fact that student numbers continue to increase might maybe point to issues on the quality of the students themselves as inputs in higher education.

\section{Conclusion}

The study clearly revealed a problem of increasing attrition rates creeping into the revered and quality-assured Zimbabwean higher education system. The fact that at present there are no publications on the issue of university attrition in Zimbabwe shows that it had never been a problem before now. Accordingly, the study recommends that the time for remedial action is at hand. It is widely acknowledged that the university sector is bedevilled with funding challenges as the economy is underperforming and the government subsidies are largely inadequate. The private sector is called upon to assist in financing university education. The government and universities should encourage these private sector players through public private partnerships as well as creating favourable environments to facilitate smooth dealings.

\section{References}

Adnett, N. (2006). Student Finance and Widening Participation in the British Isles: Common Problems, Different Solutions. Higher Education Quarterly, 60(4), 296-311. http://dx.doi.org/10.1111/j.1468-2273.2006.00325.x

Alon, S. (2005). Model mis-specification in assessing the impact of financial aid on academic outcomes. Research in Higher Education, 46(1), 109-125. http://dx.doi.org/10.1007/s11162-004-6291-x

Arulampalam, W., Naylor, R., \& Smith, J. (2005). Effects of in-class variation and student rank on the probability of withdrawal: cross-section and time-series analysis for UK university students. Economics of Education Review, 24, 251-262. http://dx.doi.org/10.1016/j.econedurev.2004.05.007

Aubyn, M., Pina, A., Garcia, F., \& Pais, J. (2009). Study on the efficiency and effectiveness of public spending on tertiary education. European Commission Economic Papers.

Bakewell, J. (2008). A university drop-out is a sign of a wider failure. Retrieved from http://www.independent.co.uk/voices/commentators/joan-bakewell/joan-bakewell-a-univ ersity-dropout-is-a-sign-of-a-wider-failure-785549.html

Bean, J.P. (1983). The application of a model of turnover in work organizations to the student attrition process. The Review of Higher Education, 6, 127-148. 
Bennett, R. (2003). Determinants of undergraduate student dropout rates in a university business studies department. Journal of Further and Higher Education, 27(2), 123-141. http://dx.doi.org/10.1080/030987703200065154

Bettinger, E. (2004). How financial aid affects persistence. In C. Hoxby (Ed.), College choices: The economics of where to go, when to go, and how to pay for it (pp. 207-238). Chicago, IL: University of Chicago Press. http://dx.doi.org/10.3386/w10242

Blanden, J., \& Gregg, P. (2004). Family Income and Educational Attainment: A Review of Approaches and Evidence for Britain. Oxford Review of Economic Policy, 20, 245-263. http://dx.doi.org/10.1093/oxrep/grh014

Blundell R., Sianesi, B., \& Dearden L. (2003). Evaluating the impact of education on earnings in the UK: Models, methods and results from the NCDS. IFS Working Paper W03/20, London.

Bound, J., \& Turner, S. (2007). Cohort Crowding: How Resources Affect Collegiate Attainment, Journal of Public Economics, 91(5-6), 877-899. http://dx.doi.org/10.1016/j.jpubeco.2006.07.006

Bozick, R. (2007). Making it through the first year of college: The role of students' economic resources, employment, and living arrangements. Sociology of Education, 83(3), 261-284. http://dx.doi.org/10.1177/003804070708000304

Braunstein, A., McGrath, M., \& Pescatrice, D. (2000). Measuring the impact of financial factors on college persistence. Journal of College Student Retention, 2(3), 191-203. http://dx.doi.org/10.2190/0TTM-U8RA-V8FX-FYVA

Bresciani, M. J., \& Carson, L. (2002). A study of undergraduate persistence by unmet need and percentage of gift aid. The NASPA Journal, 40(1), Article 7. Retrieved from http://publications. naspa.org/naspajournal/vol40/iss1/art7.

Cabrera, A. F., Nora, A., \& Castañeda, M. B. (1992). The role of finances in the persistence process: A structural model. Research in Higher Education, 33(5), 571-594. http://dx.doi.org/10.1007/BF00973759

Cabrera, L., Tomás, J., Álvarez, P., \& Gonzalez, M. (2006). The problem of university dropout. Relieve, 12(2), 171-203. http://www.uv.es/RELIEVE/v12n2/RELIEVEv12n2_1eng.htm

Carneiro, P., \& Heckman, J. (2003). Human capital policy In: J. Heckman, A. Krueger \& B. Friedman (eds.), Inequality in America: What role for human capital policies? MIT Press, Cambridge, MA.

CHE (Council on Higher Education) (2013). A proposal for undergraduate curriculum reform in South Africa: The case for a flexible curriculum structure. Pretoria.

Chen, R., \& DesJardins, S. L. (2010). Investigating the impact of financial aid on student dropout risks: Racial and ethnic differences. Journal of Higher Education, 81(2), 179-208. http://dx.doi.org/10.1353/jhe.0.0085 
Chihombori, D. (2013). Cost-sharing in higher education financing in Zimbabwe, 1957-2009. MSc thesis, Faculty of Education, University of the Western Cape.

Christie, H., Munro, M., \& Fisher, T. (2004). Leaving university early: exploring the differences between continuing and non-continuing students. Studies in Higher Education, 29, 617-636. http://dx.doi.org/10.1080/0307507042000261580

Cunha, F., \& Heckman, J. (2007). The Technology of Skill Formation. American Economic Review, 92(2), 31-47. http://dx.doi.org/10.1257/aer.97.2.31

Davies, P. (2000). Student Retention in Further Education: A Problem of Quality or of Student Finance? London, Further Education Development Agency.

Davies, R., \& Elias, P. (2003). Dropping out: a study of early leavers from higher education. Research Report 386 Department for Education and Skills.

Dearing, R. (1997). Higher education in the learning society: National Committee of Inquiry into Higher Education. London: HMSO.

DesJardins, S.L., Ahlburg, D.A., \& McCall, B.P. (2002). Simulating the longitudinal effects of changes in financial aid on student departure from college. Journal of Human Resources, 37(3), 653-679. http://dx.doi.org/10.2307/3069685

Dowd, A.C., \& Coury, T. (2006). The effect of loans on the persistence and attainment of community college students. Research in Higher Education, 47(1), 33-62. http://dx.doi.org/10.1007/s11162-005-8151-8

Draper D., \& Gittoes M. (2004). Statistical analysis of performance indicators in UK higher education. Journal of the Royal Statistical Society: Series A (Statistics in Society), 167, 449-474. http://dx.doi.org/10.1111/j.1467-985X.2004.apm12.x

Edwards, M., \& Cangemi, J.P. (1990). The college dropout and institutional responsibility. Education, 111(1), 107-116.

Einav, L., \& Levin, J.D. (2013). The Data Revolution and Economic Analysis. Working Paper No. 19035, National Bureau of Economic Research.

Feinstein, L. (2003). Inequality in the Early Cognitive Development of British Children in the 1970 Cohort. Economica, $\quad 70(277), \quad$ 73-98. http://dx.doi.org/10.1111/1468-0335.t01-1-00272

Fisher, S., \& Hood, B. (1987). The stress of transition to university: A Longitudinal study of psychological disturbance, absent-mindedness and vulnerability to homesickness. British $\begin{array}{llll}\text { Journal of } & \text { Psychology, } & 78, & 425-441 .\end{array}$ http://dx.doi.org/10.1111/j.2044-8295.1987.tb02260.x

Garwe E.C. (2014). Quality assurance in higher education in Zimbabwe Research in Higher Education Journal, 23. Retrieved from http://jupapadoc.startlogic.com/rhej.html

Garwe, E.C. (2015). Trends in Student Enrolments in Agricultural Degree Programmes in Zimbabwe. Global Studies in Education, 1(1), 46-63. 
Gayle, V., Berridge, D., \& Davies R. (2002). Young people's entry into higher education: quantifying influential factors. Oxford Review of Education, 28, 5-20. http://dx.doi.org/10.1080/03054980120113607

Griffin, A. (2007). Educational pathways in East Africa: scaling a difficult terrain. Association for the Advancement of Higher Education and Development (AHEAD) Kampala, Uganda www.ahead.or.ug

Gross, J.P.K., Berry, M., \& Reynolds, P. (2015). The Differential Effects of Financial Aid on Degree Completion by Gender. Strategic Enrollment Management Quarterly, 41-61. http://dx.doi.org/10.1002/sem3.20060

Haveman, R., \& Wolfe, B. (1993). Children's Prospects and Children's Policy. Journal of Economic Perspectives, American Economic Association, 7(4), 153-74. http://dx.doi.org/10.1257/jep.7.4.153

Henry, G.T., Rubenstein, R., \& Bugler, D.T. (2004). Is HOPE enough? Impacts of receiving and losing merit-based financial aid. Educational Policy, 18(5), 686-709. http://dx.doi.org/10.1177/0895904804269098

Herzog, S. (2005). Measuring determinants of student return vs. dropout/stopout vs. transfer: A first-to-second year analysis of new freshmen. Research in Higher Education, 46(8), 883-928. http://dx.doi.org/10.1007/s11162-005-6933-7

Hu, S., \& St. John, E.P. (2001). Student persistence in a public higher education system: Understanding racial/ethnic differences. The Journal of Higher Education, 72(3), 265-286. http://dx.doi.org/10.2307/2649332

Hwami, M. (2010). Neoliberal Globalization, ZANU PF Authoritarian Nationalism and the Creation of Crises in Higher Education in Zimbabwe. Journal of Alternative Perspectives in the Social Sciences, 2(1), 59-90.

Jensen, E.L. (1981). Student financial aid and persistence in college. The Journal of Higher Education, 52(3), 280-94. http://dx.doi.org/10.2307/1981036

Johnson, D.B. (2006). Financing Higher Education: Cost-sharing in International Perspective. In: Altbach, P.G. (ed.), Global Perspectives on Higher Education. Boston: College Centre for International Higher Education.

Johnstone, D.B. (2003). Cost-sharing in higher education: Tuition, financial assistance, and accessibility. Czech Sociological Review, 39(3), 351-374.

Johnstone, D.B. (2004). The economics and politics of cost sharing in higher education: Comparative perspectives. Economics of Education Review, 20(4), 403-410. http://dx.doi.org/10.1016/j.econedurev.2003.09.004

Kalsner, L. (1991). Issues in College student retention. Higher Education Extension Service Review, 3(1), 3-8.

Kyodo, J. (2014). Education Spending Lowest in OECD, Japan Times. Retrieved 15 September 2011 from http//:www.japantimes.co.jp 
Larsen, M.R., Sommersel, H.B., \& Larsen, M.S. (2013). Evidence on Dropout Phenomena at Universities. Aarrhus University, Copenhagen.

Leppel, K. (2002). Similarities and differences in the college persistence of men and women. Review of Higher Education: Journal of the Association for the Study of Higher Education, 25(4), 433-450. http://dx.doi.org/10.1353/rhe.2002.0021

Letseka, M., \& Maile, S. (2008). High university dropout rates: A threat to South Africa's future. Pretoria: Human Science Research Council.

Li, W. (2007). Family Background, Financial Constraints and Higher Education Attendance in China. Economics of Education Review, 26(6), 724-734. http://dx.doi.org/10.1016/j.econedurev.2007.09.001

Lockhart, P. (2004). An investigation into the causes of student drop out behaviour. Retrieved from http://www.psy.gla.ac.uk/steve/localed/docs/lockhart.pdf

Lofstrom, M.J. (2007). Why are Hispanic and African American dropout rates so high? The Williams Review, 2, 91-121.

Macgregor, K. (2007). Student drop-out rates alarming. University World News, 3. http://www.universityworldnews.com/article.php?story=20071025102245380

Makoni, K, (2007). Understanding the effects of high educational costs and incidence of Student victimization at Zimbabwe's tertiary learning institutions. Harare: ZINASU.

Mamdani, M. (2007). Scholars in the Marketplace: The Dilemmas of Neoliberal Reform at Makerere University 1989-2005. Cape Town: HSRC Press.

Mandaza, I. (1986). Zimbabwe: The Political Economy of Transition-1980-1986. Dakar: CODESRIA.

Masaiti, G., \& Shen, H. (2013). Cost Sharing in Zambia's Public Universities: Prospects and Challenges. European Journal of Educational Research, 2(1), 1-15.

McGivney, V. (1996). Staying or Leaving the Course: Non-Completion and Retention of Mature Students in Further and Higher Education. National Institute of Adult Continuing Education, Leicester, UK.

Mdepa, W., \& Tshiwula, L. (2012). Student diversity in South African higher education. Widening Participation and Lifelong Learning, 13, 19- 33. http://dx.doi.org/10.5456/WPLL.13.S.19

Meghir, C., \& Palme, M. (2005). Educational reform, ability, and family background. American Economic Review, 95, 414-424. http://dx.doi.org/10.1257/0002828053828671

Musisi, N.B., \& Muwanga, N. (2003). Makerere University in Transition 1993-2000: Opportunities and Challenges. Kampala: Fountain Publishers.

Nherera, C.M. (2000). Globalisation, qualifications and livelihoods: The case of Zimbabwe. Assessment in Education, 7(3), 335-363. http://dx.doi.org/10.1080/09695940050201343

Nordbotten, S. (2010). The Use of Administrative Data in Official Statistics - Past, Present, 
and Future - With Special Reference to the Nordic Countries. In Carlson, Nyquist and Villani (Eds), Official Statistics - Methodology and Applications in Honour of Daniel Thorburn, Stockholm University, Stockholm, Sweden, pp. 205- 223.

OECD (2001). Thematic Review of National Policies for Education: Croatia, Organisation for Economic Co-operation and Development, Paris.

Perna, L.W. (1998). The contribution of financial aid to undergraduate persistence. Journal of Student Financial Aid, 28(3), 25-40.

Quinn, J. (2004). Understanding Working-Class 'Drop-out' from Higher Education through a Socio-cultural Lens: Cultural narratives and local contexts. International Studies in Sociology of Education, 14(1), 57-74. http://dx.doi.org/10.1080/09620210400200119

Rupande, G., \& Bukaliya, R. (2013). Challenges of integrating work related learning among open and distance learning students at the Zimbabwe Open University. International Journal of Advanced Research, 1(10), 658-668.

Sanders, C. (2002). Debt grows ever bigger and even more painful. Times Higher Education Supplement, 6-7.

Singell, L.D., Jr. (2004). Come and stay a while: Does financial aid affect enrollment and retention at a large public university? Economics of Education Review, 23(5), 459-471. http://dx.doi.org/10.1016/j.econedurev.2003.10.006

Singell, L.D., Jr., \& Stater, M. (2006). Going, going, gone: The effects of aid policies on graduation at three large public institutions. Policy Sciences, 39(4), 379-403. http://dx.doi.org/10.1007/s11077-006-9030-7

Somers, P. (1995). A comprehensive model for examining the impact of financial aid on enrollment and persistence. Journal of Student Financial Aid, 25(1), 13-27.

St. John, E. P., Hu, S., \& Weber, J. (2001). State policy and the affordability of public higher education: The influence of state grants on persistence in Indiana. Research in Higher Education, 42, 401-428. http://dx.doi.org/10.1023/A:1011002808866

Thomas, L., \& Quinn, J. (2006). First Generation Entrants in Higher Education: An international analysis. Maidenhead: Society for Research in Higher Education and Open University Press.

Titus, M. (2006). Understanding college degree completion of students with low socioeconomic status: The influence of the Institutional Financial Context. Research in Higher Education, 47(4), 371-398. http://dx.doi.org/10.1007/s11162-005-9000-5

Ulriksen, L., Madsen, L.M., \& Holmegaard, H.T. (2010). What do we know about explanations for drop out/opt out among young people from STM higher education programmes? Studies in Science Education, 46(2), 209-244. http://dx.doi.org/10.1080/03057267.2010.504549

Vignoles, A. (2007). The use of large scale data-sets in educational research. London: TLRP. Retrieved from http://www.tlrp.org/capacity/rm/wt/vignoles 
Vignoles, A., \& Powdthavee, N. (2009). The socioeconomic gap in university dropouts. The BE Journal of Economic Analysis \& Policy, 9(1), 19-39. $\mathrm{http} / / \mathrm{dx}$. doi.org/10.2202/1935-1682.2051.

Walpole, M. (2003). Socioeconomic status and college: How SES affects college experiences and outcomes. Review of Higher Education, 27(1), 45-73. http://dx.doi.org/10.1353/rhe.2003.0044

Wangenge-Ouma, G. (2008). Globalization and Higher Education Funding Policy Shifts in Kenya. Journal of Higher Education Policy and Management, 30(3), 215-229. http://dx.doi.org/10.1080/13600800802155010

Whitworth, A. (ed) (2013). Evaluations and improvements in small area estimation methodologies. National Centre for Research Methods Methodological Review paper University of Sheffield. Retrieved from eprints.ncrm.ac.uk/3210/1/sme_whitworth.pdf.

Wilson, K. L., Lizzio, A., \& Ramsden, P. (1997). The development, validation and application of the Course Experience Questionnaire. Studies in Higher Education, 22(1), 33-53. http://dx.doi.org/10.1080/03075079712331381121

Woodhall, M., ed. (2002). Paying for Learning: The Debate on Student Fees, Grants and Loans in International Perspective. Special International Issue of The Welsh Journal of Education, 11(1), 1-9.

World Bank (2010). Financing Higher Education in Africa. Washington D.C: World Bank. http://dx.doi.org/10.1596/978-0-8213-8334-6

Yorke, M. (1998). Non-Completion of Undergraduate Study: Some Implications for Policy in Higher Education. Journal of Higher Education Policy and Management, 20(2), 189-201. http://dx.doi.org/10.1080/1360080980200206

Zimbabwe National Students' Union, (March 2009). Monthly Briefing Paper. Retrieved from http://www.zinasu.org

Zvobgo, R.J. (2003). The Impact of the Economic Structural Adjustment Programme on Education in Zimbabwe. The Zimbabwe Bulletin of Teacher Education, 65, 65-101.

\section{Copyright Disclaimer}

Copyright for this article is retained by the author(s), with first publication rights granted to the journal.

This is an open-access article distributed under the terms and conditions of the Creative Commons Attribution license (http://creativecommons.org/licenses/by/3.0/). 